\title{
Depoimentos
}

\section{História e ensino da história. Que história e que ensino?}

\section{Luís Reis Torgal}

Professor catedrático jubilado da Faculdade de Letras da Universidade de Coimbra e coordenador de investigação do Centro de Estudos Interdisciplinares do Século XX da UC (CEIS20)

Afinal o que é a História?

Todos falamos da História como tendo surgido com Heródoto e Tucídides, e em Portugal com Fernão Lopes, mas por vezes esquecemo-nos de que a consciência da História e a construção da História como disciplina, por assim dizer 'científica', é uma 'descoberta' do Iluminismo e do Liberalismo, ou seja dos finais do século XVIII e do século XIX. Na verdade, em Portugal também falamos de Alexandre Herculano como iniciador da historiografia moderna. No Brasil referimo-nos ao Instituto Histórico e Geográfico Brasileiro, criado em 1838, que procurava realizar um projecto de 'história nacional', cuja definição foi primeiro esboçada por Francisco Adolfo Varnhagen ${ }^{1}$, que tinha relações com Portugal, assim como Capistrano de Abreu, que se carteava com os nossos historiadores, nomeadamente com João Lúcio de Azevedo ${ }^{2}$. E dizemos ainda, no caso português, que a primeira revista de História (lato sensu) foi o O Arqueólogo Português (iniciada em 1894), dirigida por José Leite de Vasconcelos, e depois, de uma forma mais específica, o Arquivo Histórico Português, publicada de 1903 a 1917, dirigida por Anselmo Braamcamp Freire, seguida da Revista de História (1912-1927/28), da responsabilidade do intelectual nacionalista Fidelino de Figueiredo (que fez grande parte da sua vida no Brasil) e da Sociedade Nacional de História, depois oficializada com o nome de Sociedade Portuguesa de Estudos Históricos. Todas estavam ligadas, pois, à defesa da nacionalidade e do seu património. 
Falemos primeiro da consciência da História. Mircea Eliade ${ }^{3}$ insiste na afirmação de que o Cristianismo quebrou com a ideia de eterno retorno ao dar à História um princípio e um fim, um alfa e um omega. Aceitamos que sim, mas também é verdade que foi o Cristianismo que deu à História um sentido providencialista, passando ela a ser para a sociedade e para o homem (para cada um dos homens) um processo inscrito no livro da Providência divina, representado simbolicamente na afirmação comum 'Se Deus quiser..., providencialismo que agora é cada vez mais evidente nas religiões pentecostais, ou mesmo na religião católica tradicional, onde é sempre esperado o "milagre de cada dia". Foi afinal preciso todo um processo de laicização - em consequência da leitura da História através da ideia laicizada de Progresso (Condorcet ${ }^{4}$ ) e da consciência histórica hegeliana e marxista - para dar à História um sentido rectilíneo mas de construção humana. Por isso a Contra-Revolução defensora da Tradição (ou do Tradicionalismo) do 'Antigo Regime' apelava para a ideia de uma História circular, em luta contra o Iluminismo, que considerava ser um passo em frente no sentido da formação de um sistema liberalista, a que se seguiria um sistema socialista, laicista e ateísta ${ }^{5}$.

Mas será a História rectilínea? Poderemos dizer que a História se pode explicar, numa lógica filosófica e historicista, como um caminho marcado com determinados objectivos, sejam eles salvacionistas escatológicos (de tipo cristão), socialistas (sociedade sem classes), ou de tipo capitalista (o "fim da História”, de Fukuyama ${ }^{6}$ )? Karl Popper já criticara o historicismo e historiadores de inspiração marxista, como François Furet, que escreveram sobre a desilusão que provocou o comunismo de sistema ${ }^{8}$, olharam com angústia para o fim do século (século XX), concluindo que o homem deixou outra vez de pensar poder dominar a História ${ }^{9}$. Com efeito, a História — por muito que nos custe - não tem um desenvolvimento rectilíneo e a crise do início do século XXI nos Estados Unidos e depois na Europa tem provado que, apesar do progresso científico e tecnológico (que sempre, de resto, se experimentou), a sociedade não conseguiu criar formas de progresso social, a ponto de alguns pensadores afirmarem que se tratou de "uma grande ilusão"10. Não conseguiu manter os direitos ou as garantias adquiridas e vai perdendo o que se julgava impossível perder, o que leva os analistas a pensar na hipótese de recuo. Sem nos confundirmos com teses contra-revolucionárias, de eterno 
retorno naturalístico, teremos de admitir que é mais adequado aceitar a ideia de um progresso em espiral, à maneira de Vico ${ }^{11}$, que nos leva a considerar que o processo civilizacional tem recuos e avanços, passando por pontos idênticos, mas estruturalmente diferentes. Daí que se tornasse tão conhecido o único romance de Lampedusa, publicado depois da sua morte, já em 1958, magistralmente adaptado ao cinema por Visconti, Il Gatopardo (O Leopardo), onde o Príncipe de Salinas, perante a consciência de "regresso ao passado" da sociedade do Risorgimento, proferiu a famosa frase: "Se vogliamo che tutto rimanga come è, bisogna che tutto cambi" 12 , "Se queremos que tudo permaneça como está, é necessário que tudo mude". Ou, como mais vulgarmente se diz: "É preciso mudar alguma coisa para que tudo fique na mesma".

A crise do Capitalismo de hoje é idêntica, mas estruturalmente diferente, à crise do Capitalismo dos anos 20-30. Daí que seja impossível determinar um fim ou mesmo fazer uma previsão na História ${ }^{13}$. A História é sempre uma surpresa, que nos leva a pensar de forma simultaneamente pessimista e optimista ou, se quisermos, de forma realista. Olhemos, a fim de melhor entender o que dissemos, para a afirmação de François Furet, na sua correspondência com Erst Nolte:

Tal é o pano de fundo melancólico deste fim de século. Aqui estamos nós confinados a um horizonte único da história, empurrados para a uniformização do mundo e para a alienação dos indivíduos à economia, condenados a retardar-lhes os efeitos sem ter qualquer domínio sobre as causas. A história apresenta-se tanto mais soberana quanto nós acabamos de perder a ilusão de a governar. Mas, como sempre, o historiador tem o dever de reagir contra aquilo que assume, na época em que escreve, um ar de fatalidade: está farto de saber que são efémeras essas espécies de evidências colectivas. As forças que trabalham pela universalização do mundo são tão poderosas que provocam encadeamentos de circunstâncias e de situações incompatíveis com a ideia de lei da história. Por maioria de razão com a ideia de previsão possível. Compreender e explicar o passado deixou de ser coisa simples. ${ }^{14}$ 
Falemos agora da História como saber, embora não entrando em definições, tendo em conta que falo para historiadores e professores de História.

Será ela subjectiva ou intersubjectiva? Será ela uma arte? Ou será uma ciência? E poderá qualificar-se como um conhecimento objectivo?

Pela minha parte, costumo caracterizá-la como uma 'literatura científica'. 'Literatura' porque entendo que a História dificilmente tem possibilidade de abarcar a realidade 'total' (que foi uma das ilusões do marxismo e mesmo de certas correntes da chamada 'História nova', que surgiu com os Annales), por mais totalizadora que tente ser a nossa investigação e a nossa interpretação, ou seja, por mais ângulos por que tentemos tratar qualquer objecto da História, para o melhor o compreender, no seu texto e no seu contexto. A História será sempre, portanto, um conhecimento que 'lê' a realidade através de um discurso que dificilmente pode ser codificado de forma unívoca. Aliás, é hoje mais do que discutível que qualquer ciência possa ser entendida, de forma substancial, como 'ciência de rigor' em oposição às ciências sociais e humanas, naturalmente mais 'moles'. Mesmo que assumamos que a nossa linguagem usa poucos termos técnicos e esses mesmo discutíveis, porque gerais e passíveis de serem infirmados ou reduzidos a reflexões diferenciadoras (Idade Média, feudalismo, Renascimento, Iluminismo, Liberalismo, fascismo, proletariado, capitalismo, Época Moderna e Época Contemporânea, e tantos e tantos outros) e utiliza uma linguagem 'quase comum', de tipo, por assim dizer, 'literário', é, no entanto, ou deve ser entendida, como uma ciência. Claro que é uma ciência discutível e em processo de constante clarificação e discussão, de investigação sempre em progresso e em equação, sobre um material mais volúvel, menos 'material', porque a História tem o homem e a sociedade como objecto, objecto dificilmente apreendido na sua totalidade, pouco quantificável e nunca experimentável, até porque trata do homem e da sociedade no passado, ainda que se entenda que este passado não está cristalizado e é tido como elemento de um homem intemporal, que pode ser visto na dimensão do passado, do presente e do futuro. Como disse e repito, poderá entender-se que a História e as outras ciências sociais e humanas têm a sua especificidade, são distintas das ciências matemáticas e da natureza, mas isso não implica que não devam ser consideradas como ciências, ia a dizer de rigor. Será assim se entendermos como ciência uma certa atitude epistemológica e metodológica. 
Infelizmente, contudo, também por culpa nossa, de historiadores e professores de História, a nossa 'ciência' é muitas vezes entendida e apresentada como uma retórica, como um discursos pouco rigoroso, subjectivo, ou, quando muito, intersubjectivo, e, assim, afastado do universo da Ciência (com C maiúsculo). Na verdade, quantas vezes ouvimos falar de Ciência e de congressos sobre Ciência que não nos incluem? Entende-se, normalmente, que a História é um saber interessante, de que todos (ou muitos) gostam, que evocam constantemente, que utilizam num belo discurso, mas que nunca se pode colocar no patamar da Ciência ${ }^{15}$. Esquece-se afinal que a Ciência (aquela que consideram ser afinal a Ciência, as 'ciências de rigor' e as 'ciências naturais') viveu no mundo da Filosofia e da História, como saberes de reflexão, de narração e de catalogação, pelo que, quando, até ao século XX, falamos em muitas universidades de Filosofia, estamos a referir-nos ao vasto saber da Filosofia Natural, ao mesmo tempo que falamos também de História Natural, referindo-nos aos mundos da zoologia, da botânica, da mineralogia... Se essas ciências se tornaram independentes nos séculos XIX-XX, a História também, ao ponto de só então obter estatuto de ciência ensinada no âmbito das Universidades ou, latamente, do Ensino Superior ${ }^{16}$.

Para mim, a História é uma Ciência - mesmo que se diga, como afirmava Le Goff, que "não é uma ciência como as outras"17 — caracterizada pela objectividade (não utilizo a palavra "imparcialidade" que não faz parte do meu vocabulário epistemológico para definir o conhecimento histórico, pois entendo que o conhecimento é sempre "parcial", ou seja, tem um determinado posicionamento, pois o historiador vive no mundo complexo da cultura, que supõe inclusivamente a ideologia). Quando digo que a História é uma ciência objectiva não esqueço o conceito de José Mattoso de que a história é sempre "uma representação de representações", ou seja, o conhecimento histórico é 'uma representação' que tem por base os documentos, que constituem, por sua vez, 'representações', o que faz com que Mattoso acabe por oscilar entre a noção de História como ciência e como arte ${ }^{18}$. O que pretendo dizer é que o conhecimento histórico se deve aproximar o mais possível do objecto de análise a aproxima-se tanto mais quanto se alarga e aprofunda o seu conhecimento, o conhecimento do seu 'texto' e do seu 'contexto', no sentido da investigação, da narração e da interpretação (neste caso da 'escrita da História', para empregar o título da obra de Mattoso). Se caímos 
muitas vezes, e contra nós, historiadores e professores e História, numa concessão à 'subjectividade' é porque não tratamos dos objectos com rigor, não levantando constantes dúvidas e hipóteses interpretativas, não aprofundando pesquisas, não duvidando das fontes e do seu conteúdo (as 'representações' primeiras), caindo no campo da ideologia (fazendo da História uma 'interpretação ideológica' ou uma 'ideologia historiográfica'), fazendo da divulgação um belo e sedutor discurso literário mas sem objectividade.

Transcrevamos as palavras de José Matoso para melhor esclarecer esta posição, quando admite que a História pode ser considerada uma ciência:

... apesar de muitas e variadas objecções, admite-se actualmente que a História é uma ciência, e não uma disciplina literária. Quer isto dizer que propõe um discurso não arbitrário, quer do ponto de vista de conteúdo, quer do ponto de vista da forma; e ainda que reivindica a possibilidade de encontrar uma relação necessária entre o discurso e o seu objecto. E, se se pode admitir no texto literário, como em toda a produção artística (nomeadamente na música), que evoque não a ordem, mas a desordem da realidade, não a sua compreensibilidade através da demonstração da estrutura e dos seus mecanismos, mas a desorientação subjectiva do sujeito perante a dificuldade de lhe descobrir o sentido e de se orientar no meio das suas contradições, isso já não pode acontecer com a História. A História destina-se, justamente, a tentar demonstrar que existe uma ordem no mundo, e que uma das mais importantes chaves da sua descoberta é a repartição da existência em passado e presente e o estudo do passado em grandes planos, para encontrar as razões profundas dos movimentos colectivos. ${ }^{19}$

Pois partamos do princípio de que a História é uma Ciência e continuemos a analisá-la noutras perspectivas.

A História e 'as suas circunstâncias' - o valor da teoria na História

Venho ao Brasil há quase trinta anos, desde que estive em Brasília em 1984 num colóquio sobre O século XVIII e o Brasil, a representar o então ICALP (Instituto de Cultura e Língua Portuguesas), hoje Instituto Camões. Mas só 
em Outubro de 1988 participei num colóquio sobre teoria da História, mais precisamente sobre o tema Visões da História, organizado pela Pontifícia Universidade Católica do Rio de Janeiro, onde apresentei a comunicação História, consciência histórica e ideologia. A partir daí rumei ao Brasil muitas vezes, quase sempre para falar de temas relacionados com a História, a sua história e a sua teorização, porque coordenei um projecto de História da História em Portugal e no Brasil, que originou uma obra de colaboração, publicada em duas edições, infelizmente só integrando, porém, o estudo do caso português ${ }^{20}$.

Não é para falar de mim e dos projectos em que participei que aludo a estes factos. Falo deles porque foi então que melhor me apercebi de que a História aqui, isto é, tal como era pensada no Brasil, tinha diferenças significativas em relação a Portugal. Digo que 'melhor me apercebi', porque, na verdade, já o verificara, então com imenso agrado, numa altura em que a historiografia académica portuguesa assumia, normalmente, o vício narrativista e documentalista no pior sentido, com que escondia afinal a necessidade, sem por vezes o conseguir, de fugir da ideologia, de 'direita' ou de 'esquerda', de 'situação' ou de 'oposição', que marcava a História durante o Estado Novo. Refiro-me então à minha experiência de estudante de História em Coimbra, nos anos 60, mais precisamente, da cadeira de História do Brasil, quando tive a felicidade de ser aluno do Professor Guilhermino César (que era um especialista de Literatura e não de História) e que, a par de uma historiografia tradicional (Hélio Viana ou Pedro Calmon ${ }^{21}$ ), nos citava e nós líamos, ou consultávamos, a História Geral da Civilização Brasileira (1960), dirigida por Sérgio Buarque de Holanda ${ }^{22}$ ou as obras de sentido marxista de Caio Prado Júnior $^{23}$. No final dos anos 80 , quando estive no colóquio da PUC (nessa altura, em período democrático em Portugal, já falávamos à vontade, e até como uma moda, da 'escola dos Annales'), verifiquei (ou confirmei) que no Brasil o pendor teórico era muito mais evidente na discussão e na construção da História do que em Portugal. Nessa altura, e até hoje, era comum a historiografia servir-se de filósofos e sociólogos para interpretar a História, como se o seu pensamento constituísse um modelo, ou uma armação essencial na qual se inscrevessem os factos históricos. Não era só o pensamento marxista, mais ou menos ortodoxo ou heterodoxo - de Marx e Engels, mas também de Gramsci, de Rosa Luxemburgo, de Lukács, da 'escola de Frankfurt' (Horkheimer, Adorno, Marcuse, Eric Fromm, Habermas...) - a modelar a 
historiografia, mas outros (alguns ligados também ao marxismo) preenchiam a reflexão dos historiadores brasileiros, como Norbert Elias, Hanna Arendt, Walter Benjamin ou Michel Foucault.

Sem discutir a justeza ou não das considerações dos nossos colegas brasileiros, entendíamos então - e agora - que era outro o rumo da metodologia e da epistemologia históricas. Daí falarmos da 'História e das suas circunstâncias', ou seja, partindo do princípio de que, apesar da universalidade da História, ela se desenvolve de modo diferente em Portugal ou no Brasil, nos Estados Unidos ou no México, no Reino Unido ou em França. Esse conceito surge-nos por influência do pensamento de outro filósofo, espanhol e de grande influência em Portugal e talvez menos no Brasil, onde, todavia, tem sido estudado em alguns artigos que fui detectando. Refiro-me, naturalmente, a José Ortega y Gasset, cuja obra (a começar em Meditaciones de Quijote, 1914, e El tema del nuestro tiempo, 1923) defende uma lógica cartesiana corrigida, tendo em conta que a sua teoria da existência se pauta pela consciência não de um 'eu' absoluto, mas de um 'eu' relativo, posicionado em determinadas circunstâncias sociais, que se tem sintetizado na frase 'o Homem e as suas circunstâncias'.

Daqui concluo que a História portuguesa (no sentido da historiografia) não se preocupa tanto como a brasileira pela 'engenharia teórica' (que vim a verificar que é obrigatória nas teses de mestrado e de doutoramento, à qual os candidatos são obrigados a dedicar bastantes páginas). Por outro lado, a historiografia no Brasil concede um maior significado à 'história social', que supõe o 'quotidiano' e, nele, por exemplo, o campo da religiosidade, tema muito vivo aqui, mais do que nas sociedades mais laicizadas do Ocidente europeu (mesmo em Portugal), erigindo até em área autónoma do saber a 'história oral'. Aceito, pois, a diferença e entendo que em certas perspectivas a historiografia brasileira tem caminhado de forma mais decidida e inovadora do que a europeia, tal como antevi nos anos 60. No entanto, embora considere que, se História deve dar uma certa importância à teorização, julgo que esta não pode assumir a forma de modelo formatador da História, perigo em que por vezes se cai aqui, esquecendo que a nossa ciência é indutiva e assenta fundamentalmente na investigação.

De resto, vejamos o que nos diz José Mattoso. É, conforme já compreendemos, um dos poucos historiadores portugueses que, como António Manuel 
Hespanha ${ }^{24}$ ou Fernando Catroga ${ }^{25}$, escreveu páginas de teoria da História ${ }^{26}$. Numa conferência realizada na Faculdade de Ciências e Tecnologia da Universidade Nova de Lisboa, em 22 de Outubro de 1986, texto que incluiu na sua obra Escrita da História, ao falar da sua hesitação em fazer uma conferência sobre as teorias ligadas à 'escrita da História' (foi assim que intitulou a conferência e o primeiro capítulo da obra), dizia, com alguma exagerada humildade e com uma aparente contradição acerca da utilidade da teoria:

A minha insegurança resulta de uma certa aversão pessoal por questões teóricas e por noções abstractas, agravadas por uma deficiente preparação filosófica. Interessa-me a prática da lógica pela sua utilidade na produção de um discurso rigoroso e coerente, mas a metafisica deixa-me muitas vezes desorientado, com as suas generalizações demasiado amplas, as suas abstracções que depois hesito em aplicar, e a sua terminologia cheia de equivalências que afinal são menos equivalentes do que parecem. Apesar disso, estou firmemente convencido da necessidade de o historiador se apoiar no terreno conceptual, e de as opções aí tomadas serem explícitas, o que obriga ao esclarecimento prévio de muitas questões teóricas, sobretudo em matérias relacionadas com as ciências humanas, como a Sociologia, a Psicologia ou a Antropologia. De facto, as noções conceptuais fornecidas por outras ciências têm-me sido por vezes mais úteis às minhas investigações do que os modelos propostos anteriormente por colegas da minha especialidade. ${ }^{27}$

Poderia fazer minhas as palavras de José Mattoso, pois se considero que o historiador e o professor de História devem assumir uma cultura teórica assim como uma cultura prática, resultante do conhecimento das coisas da vida, até das coisas aparentemente triviais, "coisas do quotidiano", conforme desde há muito falava Marc Bloch ${ }^{28}$ - nunca devem considerar que essa cultura lhes pode servir como 'modelo' a formatar e a pautar a sua escrita da História, à maneira (num exemplo extremo) do que sucedia com a história soviética, toda ela modelada pelo marxismo, simplificado por teses de manuais oficiais ${ }^{29}$. 


\section{O ensino da História: Universidade, Cultura e Ciência}

Aproximemo-nos agora das questões do ensino da História, começando pelo seu questionamento no âmbito da Universidade ou, se se quiser, mais amplamente, do Ensino Superior.

Foi sempre uma grande questão em aberto saber o que deveria ser a Universidade e o seu ensino, não só no âmbito da História como noutras áreas do saber, assim como foi um ponto sempre problematizado, para o caso da formação dos professores, se a pedagogia e a didáctica deveriam ser ensinadas em escolas específicas de pós-graduação, Escolas Normais, como sucedeu em Portugal até 1930, ou em cursos especializados de Ciências Pedagógicas, como aconteceu até aos anos 70, ou se essas ciências se deveriam antes integrar nos cursos de Letras ou de Ciências, seguindo-se o estágio em escolas de ensino básico e secundário (como se classifica o ensino não superior em Portugal), como agora se procede. Do mesmo modo discute-se, para além da formação prática nos diversos cursos de ensino superior fundamentais, se, por exemplo, o ensino tecnológico deve essencialmente ser ministrado nas fábricas, o ensino jurídico nos tribunais ou o ensino médico nos hospitais. Essa discussão está, por certo ultrapassada, pois hoje parece indubitável que o ensino deve ter uma componente teórica e prática, sendo esta também ministrada nas universidades e institutos politécnicos e em instituições e em empresas, numa conjugação de colaborações. O difícil é, como se sabe, conseguir, na experiência, o que hoje é consensual em termos teóricos.

Mas os problemas mais complexos foram e são outros, ainda hoje, mais ligados à forma como a Universidade deve orientar o ensino, inclusivamente se ele deverá ser predominantemente profissional, 'científico' ou 'cultural'. A primeira opção levava a um ensino essencialmente funcional, a segunda a um ensino científico especializado, em que o professor ensinava fundamentalmente as matérias que investigava, integrando os alunos nessa pesquisa, e o terceiro poderia redundar no ensino de grandes sínteses, no caso da História um pouco na continuação do ensino secundário.

Ortega y Gasset deixou-nos um discurso notável, que apresentou a pedido da Federeración Universitaria Escolar de Madrid, o qual inspirou, a partir dos anos 30, do século passado, uma série de outros discursos sobre o ensino 
universitário. O seu título é exactamente Misión de la Universidad e foi apresentado em $1930^{30}$.

Ortega considerava que a Universidade tinha uma missão fundamental - a Cultura. E explica o que é Cultura: não é 'ornamento', ou erudição, mas o modo e a substância de o homem se orientar no meio do caos que constitui a vida. ${ }^{31}$ Assim, uma Universidade sem cultura não é Universidade, podendo ela criar bons profissionais e bons cientistas, mas sumamente incultos. Era essa a noção que tinha da Universidade e da sociedade europeia no seu tempo, que considerava profundamente inculta. Por isso dizia que era preciso "criar de novo na Universidade o ensino da cultura ou sistema de ideias vivas próprias do tempo"32.

Deste modo, importa salientar que três objectivos da Universidade deveriam ser prosseguidos: transmitir cultura, ensinar profissões e fazer investigação científica. Estas três realidades deveriam ser consideradas sempre no seu ensino. O papel fundamental da Universidade seria, pois, transmitir cultura, humanizar a ciência e o ensino profissional, evitando que o cientista fosse 'um bárbaro que sabe muita coisa', ou pouca coisa, demasiado especializada, e que se formassem profissionais meramente práticos.

Falámos de Ortega y Gasset porque o consideramos muito actualizado? Não é bem assim, embora por sua inspiração — como já se sugeriu — tivessem surgido pensamentos muito actuais nos anos 30 e por aí além, que eram, como hoje, anos de crise da Universidade ou do Ensino Superior. De resto, não é por acaso que a segunda edição em português da Misión de la Universidad tenha surgido no Brasil no fim do século $\mathrm{XX}^{33}$ e em Portugal, neste século XXI, curiosamente no contexto da iniciativa "Coimbra, capital nacional da Cultura" 34 , ao mesmo tempo que apareciam, nesta cidade universitária, no mesmo âmbito, traduções de textos também significativos, mas mais recentes, como os de Jacques Derrida ${ }^{35}$ e de Bill Readings ${ }^{36}$.

Devo confessar que não sei exactamente qual a identidade e qual é o estado da Universidade no Brasil nos dias de hoje ${ }^{37}$ - ainda que, todavia, participe, em fase de iniciação de um projecto de investigação sobre o tema - , embora a julgue em franco progresso ou em momento de entusiasmo, pese embora a greve de professores (que era uma situação constante, quase normal, há alguns anos). O que entendo é que na Europa e em Portugal ela passa por um tempo de crise. Daí que, como académico, tenha abordado esse 
assunto, em alguns textos recentes ${ }^{38}$. Mas é importante afirmar que entendo que a crise é um estado constante da Universidade, em qualquer tempo e em qualquer lugar.

$\mathrm{Na}$ verdade, em cada reflexão realizada ou em cada movimento de insurreição desenvolvido no meio académico, encontramos considerações críticas relativamente à Universidade (empregamos a palavra na sua dimensão colectiva, embora o mesmo se possa deparar para cada uma das universidades, ou para as universidades de um país). Constroem-se paradigmas relativamente à Universidade, mas a realidade está longe de se aproximar desses paradigmas, que funcionam sempre, por isso, na consciência de quem se debruça sobre o tema em cada época, como conceitos utópicos (que não têm ou ainda não tiveram lugar). Daí falar-se então da 'crise', que etimologicamente significa

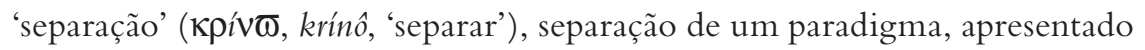
normalmente como 'tipo' a alcançar (nesse sentido Ortega y Gasset falava ironicamente das "universidades dos países exemplares", referindo-se aos modelos propostos em Espanha, como sucedia com a Universidade alemã). Noutra situação, pode igualmente considerar-se o estado de 'crise' da Universidade, quando se está em processo de construção de um outro paradigma, ao mesmo tempo que se desconstrói o já existente.

É, portanto, necessário desdramatizar essa situação de 'crise'. A 'crise' representa, normalmente, um estado de passagem, como sucede com a 'crise' do ponto de vista médico (área onde o conceito foi primeiro introduzido), que significa o estado de uma doença e de um doente, em direcção à morte ou à vida. Portanto, a 'crise da Universidade' representa um processo de alteração, para melhor ou para pior, mas sempre para um estado diferente.

Dei esta explicação, como disse, no sentido de 'desdramatizar', mas não no sentido de aliviar o peso da crise que hoje experimentamos, ou de branquear situações. O certo é que os Estados Unidos da América e a Europa, sobretudo nos países periféricos e dependentes, como o nosso, passam por uma das maiores crises económicas, financeiras, políticas e culturais de que há notícia. E a Universidade faz parte dessa crise, ao invés do que dizem certos notáveis universitários que entendem que a Universidade cumpriu o seu dever formando um número nunca atingido de diplomados e especialistas, uma 'massa crítica' (conceito formado primeiro no domínio da física e que se adaptou às análises de sociologia cultural, tornando-se uma verdadeira moda 
vocabular), que a sociedade não soube integrar, quando deveria ter aproveitado as suas potencialidades para criar estruturas económico-financeiras, políticas e culturais, sempre referidas pelos analistas, mas nunca alcançadas.

O facto é que o economicismo do tempo - primeiro 'economicismo de sucesso', de produção e de consumo, com ideias-chave como 'competitividade', 'competência' e 'excelência', depois 'economicismo de crise', utilizando todas as formas para economizar, numa lógica de austeridade e de pobreza - gerou as noções de 'ciência produtiva', de 'universidade empresa', de 'normativização', de 'performance', que caracterizam o universo do saber neste início do século XXI, marcado por uma lógica neoliberal e de globalização negativa (ressalvando e relevando o que de positivo pode ter, e tem, sem dúvida, o conhecimento global) e de desenvolvimento tecnológico. ${ }^{39}$

Ao invés da ideia da Universidade democrática e independente, científica e cultural, que defendo, o Ensino Superior tornou-se massificante, resultando daí um abaixamento geral de nível do saber. O processo de Bolonha, ao invés da sua declaração essencial, assinada na cidade que conheceu a primeira Universidade europeia, em 19 de Junho de 1999, gerou licenciaturas (1. ${ }^{\circ}$ ciclo), mestrados $\left(2 .^{\circ}\right.$ ciclo) e doutoramentos ( $3 .^{\circ}$ ciclo) que cada vez menos demonstrarão uma formação rigorosa e exigente e, ao contrario, manifestarão uma formação cada vez mais abrangente, de carácter pretensamente interdisciplinar (no sentido da criação de competências múltiplas) e menos especializada. A multiplicação de Universidades, nomeadamente Universidades e Institutos Politécnicos privados ou empresariais (num regime de Ensino Superior, como o português, classificado de 'binário'), com vários pólos, e de cursos, com especificidade discutível, gerou um mundo de falsas competências, que em parte explicam a grande percentagem de diplomados universitários desempregados ou subempregados. Por sua vez, a diminuição de professores, em número e em qualidade, torna a formação cada vez menos exigente. A forma sobrepôs-se aos conteúdos e, no domínio do ensino, afirmou-se o império das ciências pedagógico-didácticas, que criaram o que o actual ministro da Educação, Nuno Crato (agora também pressionado pelo economicismo que leva a medidas ditadas mais pela austeridade do que por medidas pedagógicas), antes de ser governante, intitulou, numa expressão irónica e feliz, o "eduquês" ${ }^{\text {", }}$, situação para que havia eu, há muito, criado o conceito mais prosaico de 'panpedagogismo'. 
A par disso, afirmou-se o abuso de rankings, da indexação de citações, da avaliação sem sequência e do império das agências que fazem esse tipo de análise, e o aumento incrível da burocracia, que passou a constituir uma das tarefas mais significativas e mais árduas dos docentes. Daí a falta de tempo de que os professores se queixam e a formação de centros e laboratórios de investigação, por vezes independentes das faculdades, onde se tenta praticar, de forma mais efectiva e regular, a investigação científica, com o apoio das instituições de pesquisa, como sucede em Portugal com a Fundação para a Ciência e a Tecnologia ${ }^{41}$ e outras fundações privadas de utilidade pública.

À falta de tempo dos professores para a investigação, junta-se - devido em parte à transformação das disciplinas anuais em semestrais, que prejudica a exposição e a assimilação do saber, sobretudo em áreas como a História, que é uma ciência do tempo e que tem de ser aprendida com tempo - a falta de maturação pela parte dos estudantes para as suas leituras e reflexões, que, inclusivamente, os têm afastado de conferências e colóquios, onde a sua presença se fazia sentir. Essa situação assemelha-se muito à crise dos anos 30, o tempo em que reflectia Ortega, ou Joaquim de Carvalho, um dos melhores filósofos e historiadores da filosofia e da cultura que tivemos. É seu um notável artigo, com o título sugestivo Reflexão outonal sobre a Universidade de todo o ano, publicado no Diário Liberal, de Lisboa, em 8 de Novembro de $1933^{42}$. Respigo desse notável texto as seguintes palavras de crítica ao ensino universitário:

Percorra-se com espírito equânime o plano de estudos de algumas, senão de todas as Faculdades, e a peçonhenta verdade da carência de tempo livre, para mestres e estudantes, surgirá com profunda evidência. Atirado de uma cadeira para outra cadeira, de um curso para outro curso, das aulas teóricas para as aulas práticas, o professor é inexoravelmente compelido à burocratização do magistério, ao ensino fácil e à repetição - coisas terríveis para mestres e alunos.

Para mestres, porque lhes cerram o intelecto à imaginação criadora e os convertem em provincianos do Espírito, e para os estudantes, porque lhes geram a sensação de que a aprendizagem não exige o esforço diário e a ciência é como os frutos maduros, que estão acolá à espera de quem os colha. 
$[\ldots]$

Escolar, estudante e estudioso são três palavras diversas, cuja diversidade não impede que toda a gente lhes reconheça o parentesco de membros de uma única família. Ser escolar é adquirir o direito de frequentar as aulas; ser estudante é, pelo menos, cumprir suficientemente os deveres da escolaridade, mas o ideal é que os escolares e os estudantes sejam estudiosos, e ser estudioso na juventude não tem a significação farisaica do jovem limitar as suas vigílias, as suas curiosidades e a sua formação interior [...] aos estudos oficiais da Universidade.

Todo o jovem que transita durante cinco anos por uma Faculdade e viveu à margem dos problemas eternos, dos anelos do seu tempo e não ouviu a tenuíssima voz das gerações, que nos estão dizendo ser a ciência difícil e um esforço infatigável e sem descanso, frustrou a sua vida para sempre.

Pode ser um técnico útil, mas é uma alma perdida e a arrepiante verdade é que a organização vigente é uma máquina infernal de perda de almas. Costuma dizer-se que a juventude é a idade heróica, mas é, pelo menos, a única idade da vida que tem o direito absoluto ao desperdício do tempo em holocausto às nobres paixões. A ciência oficial não é toda a ciência e menos ainda toda a cultura, e o grande pecado da organização em vigor é roubar o tempo e supor que propicia ao estudante o viático intelectual para toda a vida pós-escolar.

Era, pois, uma 'universidade cultural' que Carvalho também defendia. E nessa defesa - tal como Ortega y Gasset, que entendia que a Europa estava, utilizando uma imagem curiosa, de pés voltados para o ar e de cabeça para baixo - olhava severamente para os tempos que corriam:

Os despojos da mortífera peçonha estão aí, bem visíveis: a crescente diminuição de vocações científicas, a quebra de continuidade no ensino dos grandes mestres finados, a carência apavorante de jornais e revistas da juventude escolar [...]. Podemos nós, os que nos preocupamos com a saúde moral e política da nossa Pátria, ser indiferentes ao brado de alerta contra a mortífera peçonha? Este é o facto nu e 
cru, e é sobre o facto, em si, descarnado e sem tintas de retórica, que deve incidir a atenção pública. Quem há aí que não sofra com magoada indignação o justificado retraimento dos nossos editores e o crescente desinteresse por tudo - tudo - que afirme qualquer faceta do Espírito?

Dir-se-ia que vivemos submergidos por uma vaga de estupidificação colectiva, mas o nosso dever elementar, espere-nos ou não o sucesso, mesmo sem esperança de êxito, é remar contra a vaga.

Mas uma Universidade Cultural, já o dissemos, não exclui, obviamente, o desenvolvimento da Ciência e a formação de profissionais nas diversas áreas. Mas, a Cultura (que supõe a Ciência) é, afinal, o que faz da Universidade a Universidade.

Investigação e ensino da História na educação básica e secundária

Perdoem usar as designações próprias de Portugal, mas creio que facilmente fazem a transferência para o caso do Brasil. Suponho que o ensino básico corresponde hoje, no Brasil, sensivelmente ao ensino fundamental, e o secundário ao ensino médio.

Quando falamos do ensino da História, estamos afinal a falar de outra categoria da História ou de outras categorias, pois o ensino supõe a divulgação da História ${ }^{43}$. E a divulgação, para além da própria Ciência que a sustenta ou deveria sustentar, supõe (não nos iludamos) a Memória e a Ideologia, e implica formas de chegar a camadas mais jovens ou adultas, através de instrumentos de comunicação e de técnicas e saberes teóricos e práticos, em que a didáctica, a pedagogia e a psicologia são fundamentais. Ou seja, o facto de termos falado de 'panpedagogismo', como sendo um defeito do ensino do nosso tempo, não nos leva a afirmar que esse tipo de ciências e de práticas não são importantes. O que criticamos é o seu abuso, a ponto de a Associação de Professores de História, que foi criada em Portugal, em 1981, para estabelecer uma relação entre professores de todas as categorias de ensino e que - tendo em conta os objectivos fundamentais que presidiram à sua formação ${ }^{44}$ organizou excelentes colóquios e congressos, sobre a História na sua substância, e sobre o seu ensino, hoje tenha enveredado, sobretudo, por cursos

\section{Maracanan}


acerca das práticas pedagógicas e didácticas, esquecendo ou marginalizando a reflexão actualizada sobre as diversas matérias da História.

Deve, porém, dizer-se que - conforme notámos num livro que escrevemos há uns anos ${ }^{45}$ - a ideologia política directa foi tendo um papel cada vez menos importante nos programas e nos manuais de História. Ela surge, fundamentalmente, num tempo de ideologia forte, hegemónica, autoritária e mesmo totalitária. Assim sucedeu nos anos 30-40 do Estado Novo de Salazar, o 'fascismo à portuguesa', quando os manuais eram marcados pelo selo da ideologia. Era fácil encontrar neles um discurso que punha em destaque determinadas épocas, ideias e figuras históricas, como 'construtivas', considerando outras como 'destrutivas'. Assim, eram valorizadas as épocas da Fundação da Nacionalidade, a Idade Média, modelo da formação de um Estado Corporativo de inspiração católica, da Expansão, que significava a difusão pelo Mundo dos valores portugueses (bem diferente do Renascimento de outros povos), e da Restauração, que representava a reafirmação do nacionalismo português, frente à Espanha, católica também mas imperial. Depois, a par do desenvolvimento que significava o Pombalismo, com as suas 'heterodoxas' doutrinas iluministas 'estrangeiradas' - daí que o Marquês de Pombal, com o seu autoritarismo, fosse interpretado de modo contraditório e ambíguo —, iniciara-se o processo de 'desconstrução' do Estado Tradicional, o que continuara com o liberalismo e com o republicanismo 'de sistema' (não tanto o regime, porque havia que salvar o regime republicano que Salazar adoptara), que criou uma 'balbúrdia sanguinolenta', só terminada com o Estado Novo, espécie de 'regeneração', que representaria, por assim dizer, o 'fim da História'.

Se este processo de ver o curso da História é evidente - como é idêntico o processo de ver a História Universal, onde a Revolução Francesa ocupava o papel de mola destruidora do desenvolvimento 'natural' da História — nos compêndios para a Instrução Primária de Tomás de Barros ${ }^{46}$, ou para a Instrução Secundária de Alfredo Pimenta ${ }^{47}$ e de António Gonçalves Mattoso ${ }^{48}$ dos anos 30 e inícios de 40, também o é na 'História contada à crianças', de Adolfo Simões Müller ${ }^{49}$ ou de Olavo d'Eça Leal ${ }^{50}$, que analisámos, em parte, por inspiração da obra de Marc Ferro ${ }^{51}$, ou na obra de divulgação História de Portugal de João Ameal152. Mas com o fim da II Guerra Mundial e, sobretudo, nos anos 60, a visão da História dos manuais torna-se menos ideológica, ainda que nunca deixasse de ecoar o sentido nacionalista da História de Portugal, 
que a partir de então se envolve em 'campanhas ultramarinas' (na linguagem oficial) ou na 'guerra colonial' (como é costume hoje dizer-se).

Com o 25 de Abril de 1974 - marcado pela democratização, mas primeiro por uma lógica marxista de 'sociedade sem classes' — surgiu, inicialmente, nos manuais, uma ideologia socialista, que se foi esfumando e que veio a ser substituída por uma ideologia pedagogista, que marcou a generalidade dos compêndios (onde a abundância de palavras foi substituída pela superabundância de imagens, acompanhada por uma linguagem esquemática), os programas, a organização e reorganização curricular e mesmo a postura dos professores, cada vez menos exigentes e que agora enfrentam uma 'massa' de alunos cada vez menos interessada pela História, como - deve dizer-se - pela Matemática ou pelo Português (hoje a braços com a aplicação do discutível acordo ortográfico e com as novas designações gramaticais, que têm provocado protestos de professores, de linguistas, de escritores, de outras gentes de letras ou mesmo de cidadãos comuns ${ }^{53}$ ). Ou seja, o que se considera é que estamos a passar por uma crise no Ensino em geral, e não apenas no Ensino Superior, que tem afastado docentes da sua formação substancial na área da História e alunos de uma aprendizagem exigente.

Obviamente que não se deseja que todo o professor de História seja um investigador profissional, mas pretende-se que seja um investigador das matérias que ensina, na lógica de que a boa síntese supõe uma análise e que a divulgação (a qual significa tornar o conhecimento 'vulgar', ou que o faz chegar ao 'vulgo', através de um discurso claro mas rigoroso) supõe a investigação, afastada o mais possível das ideologias e da força de memórias forjadas.

Para melhor entendermos o que queremos dizer, olhemos ainda para relação da História com a Ideologia, por outros prismas, e para a relação da História com a Memória.

\section{História, Ideologia e Memória}

O historiador e o professor de História investigam e ensinam tendo como pano de fundo a Memória e a Ideologia. Daí que, se não procederem a uma análise criteriosa, podem interpretar a representação que é sempre a História de um modo formatado. Na verdade, a sociedade política ou o homo politicus tem a História como elemento fundamental ao serviço do seu discurso e da 
criação de produtos de ideologia e de memória. Cada um tem no fundo, mesmo sem o saber, uma certa ideia da História. Nietzsche considerava, como se sabe, a importância da memória no Homem, quer como factor de conhecimento quer como factor de esquecimento, considerando mesmo que o acto de ultrapassar a memória constituía a base fundamental para criar uma sociedade nova ${ }^{54}$, motivo por que é sempre apresentado (em certo sentido injustamente) como inspirador das novas gerações nazifascistas.

Os lugares da memória (e da ideologia) são assim feitos e refeitos. Os compêndios de História, a 'história contada às crianças', os livros de divulgação, os romances históricos, os museus, a toponímia e as estátuas, o próprio cinema (nomeadamente o cinema de fundo histórico), agora os portais, os sites ou os 'sítios' (como já se diz em português) e os blogues, podem ser entendidos também, para além de lugares de conhecimento e de opinião, como lugares de memória (e de ideologia), que agem eficazmente sobre as nossas actividades de investigadores e de professores de História, mas ainda muito mais sobre os aprendizes de História e sobre o cidadão comum que sempre se vai interessando pela História. É, por isso que, quando há uma mudança de regime ou de sistema político, ou mesmo a mudança de um partido político à frente do Governo, há sempre a intenção de mudar, não só através de medidas de organização do presente, mas também através de novas visões da História.

Quando muda um sistema político — ou mesmo quando ele entra em decadência que anuncia a sua morte - é fácil perceber como se alteram os objectos de memória (e de ideologia) adaptando-se, na feliz expressão de Marc Ferro, às "novas legitimidades históricas". Falámos de compêndios marcados pela ideologia do Estado Novo, mas dissemos também que a sua ideologia foi empalidecendo à medida que o tempo corria, nos anos 60 e 70. E foi assim que, logo após o 25 de Abril de 1974, surgiram novos compêndios, marcados por outras ideologias, outras memórias e outras pedagogias. O mesmo sucedeu com a 'história contadas às crianças': curiosamente a Historiazinha de Portugal de Adolfo Simões Müller foi-se adaptando ainda, durante algum tempo, às 'novas legitimidades', assim como foram surgindo também algumas 'novas histórias' que continuavam a defender um fundo nacionalista e tradicionalista, como a de António Manuel Couto Viana ${ }^{55}$; no entanto, surgiam outras 'novas histórias' pautadas por ideias diferentes, adaptadas ao fundo democrático que foi surgindo, como os best-sellers que 
constituem os livros de Ana Maria Magalhães e de Isabel Alçada, da colecção Viagens no tempo ${ }^{56}$.

Relativamente ao Brasil, analisámos o caso do significado do livro de Viriato Corrêa $a^{57}$, com o seu 'ufanismo' (para empregar uma expressão tipicamente brasileira, derivada do título da obra de Afonso Pena ${ }^{58}$ ), mas vimos também como surgiram 'novas legitimidades' com o advento de uma 'história social' que fez criar novas interpretações, como é visível na colecção O cotidiano da História. Por outro lado, notámos que o referido 'ufanismo' se afastava do nacionalismo mais tradicionalista português que, como vimos, via na Revolução Francesa o grande momento de desconstrução de uma história tradicional, ou 'natural', ao passo que no caso brasileiro jamais a Revolução foi assim entendida, pois foram as suas ideias que despertaram o sentido de independência do Brasil ${ }^{59}$.

Passando aos lugares de memória, é notória a mudança e a adaptação às 'novas legitimidades'. Surgem nomes de ruas e de praças recordando novos 'heróis' ou os novos tempos de mudança. Só para dar um exemplo, em quase todas as cidades existe uma praça ou uma rua 25 de Abril. Mas também houve uma mudança de nomes, apagando-se a memória do sistema salazarista-marcelista e avivando a memória de novos factos e personalidades. Em Lisboa a ponte Salazar (Salazar foi apagado dos nomes de todas as ruas, com algumas excepções) deu lugar ao nome de ponte 25 de Abril; em Coimbra, a avenida Arantes e Oliveira, ministro das Obras Públicas no Estado Novo, deu origem à avenida general Humberto Delgado, candidato pela oposição à Presidência da República em 1958 e um dos mais activistas oposicionistas ao regime de Salazar, tendo sido assassinado pela polícia política em 1965, e o bairro marechal Carmona, o Presidente da República mais carismático do regime (desde 1926, durante a Ditadura Militar, a 1951, ano da sua morte), deu lugar ao bairro general Norton de Matos, membro do Partido Democrático na I República, de que foi ministro, e candidato pela oposição à Presidência da República em 1949.

Quanto aos nomes de escolas, também é curiosa a mudança, que, de resto, também já se tinha operado na passagem da I República para o Estado Novo. Por exemplo, o Liceu D. Manuel II (o nosso último rei), no Porto, deu origem à Escola Secundária Rodrigues de Freitas, o primeiro deputado republicano, durante a Monarquia Constitucional, e, em Coimbra, o Liceu D. João 
III (o rei que transferiu a Universidade de Lisboa para Coimbra, em 1537, mas que também conseguiu junto do Papa que fosse criado em Portugal o Tribunal da Inquisição) deu lugar à Escola Secundária José Falcão (lente de Matemática na Universidade e autor da Cartilha do Povo, tornando-se uma das figuras mais carismáticas do republicanismo durante a Monarquia).

Se as estátuas não foram em geral destruídas, em Portugal, com excepção da estátua de Salazar em Santa Coma Dão, município onde fica a sua terra-natal (Vimieiro), em países africanos agora independentes, como Angola, Moçambique, Guiné ou mesmo São Tomé e Príncipe, com excepção de Cabo Verde, foram retiradas do seu lugar as que representavam (ou que se considerava representarem) o "colonialismo" e, em certos casos, colocadas em museus e fortalezas. Do mesmo modo, foram substituídos os nomes portugueses de algumas cidades ou regiões, como, por exemplo, Lourenço Marques, capital da colónia de Moçambique, que deu a vez a Maputo, ou Sá da Bandeira e Nova Lisboa (em Angola), que passaram a ter os nomes indígenas de Lubango e Huambo, ou Teixeira Pinto (na Guiné) que se transformou em Canchungo. De forma idêntica, aconteceu com as estátuas comunistas, na Hungria ou na Rússia, onde, por outro lado, em San Petersburgo (Leninegrado, durante a URSS), a igreja de Nossa Senhora de Kazan em 1932 se transformou em Museu do Ateísmo, extinto durante a perestroika, surgindo o Museu das Religiões, agora noutro local, para hoje voltar a ser a igreja que evoca uma das imagens mais populares da religião ortodoxa russa.

Como se vê, as alterações de 'legitimidade histórica' tanto se dão na passagem de sistemas 'fascistas' para sistemas democráticos, como de sistemas comunistas para sistemas democráticos ocidentais, nos quais reaparece, por vezes, uma certa saudade pelos regimes autoritários-totalitários e pelos seus líderes. Se Hitler ainda é na Alemanha uma figura que se procura esquecer, apesar dos surtos ocasionais de neo-nazismo, no mausoléu da família de Mussolini em Dovia di Predappio (Forli, Emília Romagna), ainda hoje se venera o Duce, sobretudo em dias de aniversário. No pequeno cemitério do Vimieiro (Santa Comba Dão, Viseu), a campa rasa onde Salazar jaz é também objecto de alguma veneração, assim como sucede no Museu da República do Palácio do Catete com o quarto onde Getúlio Vargas se suicidou. E também ali no Vimieiro, terra natal de Salazar, há certo movimento de reabilitação do 'Chefe' do Estado Novo, com um projecto muito contestado, da iniciativa 
do próprio município de Santa Comba Dão, para reabilitar a sua casa - o que, de resto, não é o mais significativo, já que a comuna de Predappio fez o mesmo com a casa natal de Mussolini — , mas também para a tornar um lugar de turismo museológico de um 'homem da terra', ao mesmo tempo que particulares se preparavam para oficializar a marca 'Salazar', atribuída, por exemplo, a uma marca de vinhos, dado que a região é famosa pelos vinhos do Dão. Aliás, o mesmo se faz em Espanha, onde, todavia, a mudança dos nomes de ruas e de praças não foi tão significativa (continua a haver algumas com o nome do generalíssimo Franco, como se mantêm os seus símbolos, por exemplo num dos medalhões da Plaza Mayor em Salamanca, ou ruas com o nome de José António Primo de Rivera, fundador do movimento falangista). Se consultarmos o site da Fundación Nacional Francisco Franco, cujo objectivo é difundir a ideologia franquista, veremos que a memória de Franco é ainda muito forte, com apelo até à compra de recuerdos, como os ricordi de Mussolini se vendem em lojas de Predappio.

Mas, mais importante do que isso, foi a polémica que a Real Academia de la Historia suscitou, ao publicar um Diccionario Biográfico Español, onde algumas figuras franquistas eram elogiadas, ou, pelo menos, branqueadas, a começar em Francisco Franco. Tal situação, provocada por uma instituição, por assim, dizer oficial, originou uma grande discussão entre alguns cidadãos e nos meios académicos, o que levou a que historiadores publicassem uma obra de crítica às biografias da Academia, que tem o título bem significativo de En el combate por la Historia. La República, la Guerra Civil, el Franquismo ${ }^{60}$. A revista La aventura de la Historia, uma revista de divulgação, dava à notícia o sugestivo título: Historiadores en las trincheras ${ }^{61}$.

Em Portugal, como já se sugeriu, a defesa de Salazar é menos significativa e só aparece em grupos até ao momento de pequena expressão e não na Academia Portuguesa da História, que soube, pelo menos em parte, adaptar-se aos tempos da democracia, ainda que tivesse sido fundada em 1937, durante o Estado Novo, com um propósito nacionalista e religioso. Todavia, numa estação televisiva do Estado (RTP1), num programa da BBC adaptado ao caso português, intitulado Grandes Portugueses, em que se votaram as 'grandes figuras da história de Portugal’, surpreendentemente (ou não), acabou por ser eleito Salazar, ainda que a eleição tivesse sido feita sem o mínimo de rigor, mas de forma a dinamizar pequenos grupos de pressão. Seja como for, 
ficou na memória de alguns que Salazar foi considerado 'o maior português', seguido, de forma não menos surpreendente, do carismático secretário do Partido Comunista Álvaro Cunhal! E o que é mais de lamentar é que o programa - realizado em sessões com pompa e circunstância - contou com a colaboração de alguns historiadores e intelectuais de várias ideologias que, num seguidismo inqualificável, não entenderam o logro e o perigo que este tipo de 'sufrágio' poderia significar. Perdoem a imodéstia, mas a minha participação no primeiro programa, realizado no Palácio de Queluz, teve como objectivo, assumido desde logo no contacto que tive com a apresentadora que me convidou (Maria Elisa), denunciar esse logro e esse perigo. Depois, tive de intervir num blogue que foi propositadamente feito para o programa, da responsabilidade da própria RTP, e escrevi alguns artigos sobre o tema e sobre um livro que surgiu na sequência desse concurso, da autoria do 'defensor de Salazar' (cada um dos dez mais votados teve um 'defensor'), Jaime Nogueira Pinto - que, deve dizer-se, sempre se afirmou como homem de 'direita' —, obra que intitulou, significativamente, António de Oliveira Salazar. O outro retrato ${ }^{62}$.

Ou seja, é fundamental que todo o historiador e todo o professor de História estejam atentos a esta questão que sempre se coloca — sobretudo à medida que entramos no mundo da divulgação e falamos da história dita "contemporânea" - de ligação do conhecimento histórico à ideologia e que se torna fenómeno de memória.

De resto, foi essa atenção que me levou a coordenar e a redigir parte de uma obra sobre o cinema no tempo de Salazar ${ }^{63}$, com algumas reflexões que depois vim a fazer também sobre o cinema do pós-25 de Abril. Com efeito, como historiador do Estado Novo (e inspirado um pouco na obra de Marc Ferro $^{64}$ ), e também como cinéfilo, percebi a importância de desconstruir um tipo de cinema normalmente de grande popularidade, para entender como nele ia penetrando a ideologia salazarista que, se era evidente no domínio do cinema de propaganda, fosse do tipo "documentário" fosse do tipo de ficção, e mesmo em algum cinema de fundo histórico, já não era tanto no drama (onde o fado era uma constante) ou na comédia. E verifiquei também - como o fizeram outros historiadores e estudiosos do cinema - que se foi desenrolando, sintomaticamente, à medida que o regime de Salazar-Caetano ia decaindo, um processo evolutivo, com a passagem do nacionalismo para 
o neo-realismo e para o 'cinema novo', respectivamente, nos anos 50 e nos anos 60-70. O próprio cinema do pós-25 de Abril tem sido feito com a memória do cinema e com a memória da história, tendo presente a sociedade do passado e a sociedade de hoje, que tem problemas por vezes idênticos àqueles existiam na sociedade de pobreza (sempre encoberta ou disfarçada) do Estado Novo.

Ainda hoje se pode ver o cinema dessa época, e também programas televisivos que o analisam e desconstroem, como acaba de suceder com o programa de António Pedro Vasconcelos em que participei, intitulado, significativamente, Sonhar era fácil, inspirado no título de um filme de 1951, Sonhar é fácil, de Perdigão Queiroga.

No pós-25 de Abril foram feitos alguns programas do ponto de vista histórico com algum interesse, sobretudo relacionados com a "Guerra Colonial", com o despertar da democracia em 1974 (sobretudo por altura dos aniversários do 25 de Abril) e com a República, cujo primeiro centenário se verificou em 2010-2011, ou, mais genericamente, sobre a sociedade contemporânea e o seu processo de desenvolvimento. Claro que esses filmes, feitos para a televisão e, na maioria dos casos, editados depois em vídeo e mais recentemente em DVD, são reveladores de ideologias — no caso, as mais evidentes poderão classificar-se de ideologias 'republicanas' e 'democráticas' —, mas o pequeno ecrã não deixou de continuar a ser marcado pelas ideologias do Estado Novo, ainda que de forma encoberta. Referimo-nos à presença constante, na RTP, de programas de José Hermano Saraiva (há pouco tempo falecido), que foi professor de História nos liceus e foi o último ministro da Educação Nacional de Salazar e o primeiro de Marcello Caetano. Os seus vários programas de História, onde se revela um notório poder de comunicação, um nacionalismo brando e um sentido regionalista, têm atraído gerações de espectadores e mesmo compradores de vídeos e de DVDs, pois trata-se dos únicos programas da televisão de História generalista apresentados com carácter regular e desde há muitos anos. Isto se exceptuarmos o que é transmitido pela estação "História", em circuito fechado (por TV-cabo ou por satélite), que hoje dá uma tal dimensão alargada à História que, quando o vejo, me faz lembrar uma afirmação de Paul Veyne ${ }^{65}$ que adaptei a uma certa realidade historiográfica e que cito por vezes com ironia 'tudo é História, logo a História não existe'. 
Nesta reflexão tem faltado uma referência a revistas de divulgação, apenas falada de passagem em relação ao caso espanhol. E o certo é que em Portugal - e também no Brasil — houve (ou há) algumas com certo significado. Uma delas surgiu no tempo do Estado Novo e, ao invés do que se poderia pensar, não emitiu uma mensagem coincidente com a sua ideologia. Era seu director e quase redactor único Rocha Martins, um monárquico liberal que se veio a revelar como um dos oposicionistas do Salazarismo mais conhecidos em termos jornalísticos. A sua revista Arquivo Nacional ainda durou alguns anos, de 1932 ao início dos anos de 1940. Só muito mais tarde, já depois do 25 de Abril, em 1978, surgiu uma outra revista de divulgação, que teve a colaboração de historiadores de nomeada. Tratou-se da revista História, nome idêntico a semelhantes revistas que já se publicavam em França e em Espanha. Foi perdendo, no entanto, o carácter de 'revista de historiadores de referência', publicando trabalhos de investigadores juniores, em início de carreira. A sua imagem acabou, todavia, por ser recuperada anos mais tarde, como revista essencialmente dedicada à História Contemporânea — que se tornou uma área preferencial, o que denota uma certa tendência ideológica para o 'presentismo' —, por um 'historiador de referência' nessa área, Fernando Rosas, com a colaboração de um historiador mais jovem, mas conhecido pela sua reflexão profissional sobre a História do século XX, Luís Farinha. A revista História veio, contudo, a terminar recentemente, mantendo-se hoje apenas, com algum interesse, os números ocasionais e temáticos publicados pela revista Visão.

Estas reflexões - necessariamente apresentadas de forma genérica e talvez um pouco desorganizada, apenas para nos chamar a atenção para a necessidade de pensarmos a História em todas as perspectivas, de forma 'poliédrica' (no dizer de Fernando Catroga), e sempre de modo problematizador - caminham para o seu termo, com algumas prevenções que foram já sendo feitas no decorrer destas linhas e palavras.

Vou agora, no ponto seguinte, referir outra faceta da memória, que revela como a ideologia imprime um certo significado à História quer para a salientar e recordar, até como meio de afirmação da cidadania no presente, quer para a esquecer, omitindo aspectos significativos dessa ligação. Neste caso, a crise da cultura e da consciência cívica, que se revela no nosso mundo político e que considero ser um preço da massificação, do presentismo e do 
economicismo da sociedade dos dias de hoje, que conta sobretudo com o factor "produção" e com um saber contabilizado, leva, como veremos, a um esquecimento da História.

Tomando as palavras do escritor catalão Carlos Ruiz Zafón, autor de uma tetralogia (ainda não completa) chamada O cemitério dos livros esquecidos, a propósito da sua experiência de Los Angeles e que poderia ser alargada a outras situações, mesmo a certos momentos e 'circunstâncias' ocorridos no nosso quase milenário país, "dei comigo a pensar no facto de estar a viver numa sociedade onde a memória se apaga cada manhã”. E continuo com a cor da sua frase literária: "Parece que quem lá vive faz questão de esquecer tudo o que viveu na véspera. Havia tacitamente um processo de destruição da memória". ${ }^{66}$

Com efeito, é esta a sensação que por vezes tenho quando observo o que se passa à minha volta, quando olho para a falta de memória dos políticos prefiro chamar-lhes a "gente dos partidos" - dos nossos dias, em Portugal e noutros países da Europa e do Mundo. O exemplo que vou apresentar é apenas um caso e não é, sem dúvida, o mais significativo. Mas é um caso actual, cuja história deve ser contada desde o início — o modo como tem sido tratada, e sobretudo como foi tratada hoje, a 'celebração do tempo', analisando em especial 'o caso dos feriados'.

Memória e esquecimento: a 'celebração do tempo' — o caso dos feriados em Portugal

Ninguém melhor que Fernando Catroga ${ }^{67}$ estudou o caso da celebração do tempo histórico em Portugal, sobretudo no que respeita aos centenários, no que foi seguido por alguns colegas mais novos, de que saliento os casos de Sérgio Campos Matos (mais interessado, contudo, nas áreas da memória na sua relação com a historiografia e o ensino da História ${ }^{68}$, razão porque cheguei a pensar sugerir o seu nome para proferir esta lição), de Maria Isabel João ${ }^{69}$ e de Luís Oliveira Andrade ${ }^{70}$, falecido muito jovem e cujo trabalho prossegui ${ }^{71}$.

O acto de celebrar os centenários, fazendo de cem anos passados (ou dos seus múltiplos, ou de cinquenta anos, meio século, ou mesmo de 25, um quarto de século) motivo de comemoração está ligado inicialmente à 
liturgia cristã. A pouco e pouco surge no âmbito da sociedade paulatinamente secularizada, a partir dos finais do século XVIII, e, como sistema, no contexto da afirmação do Positivismo de Augusto Comte. É então que desponta a ideia de um calendário de celebração do passado ('os mortos governam os vivos'), ao invés do calendário republicano da Convenção Francesa (1793-1795), ligado ao presente revolucionário. Os centenário fazem, pois, parte do catecismo positivista, ou da sua 'religião', que, se em Portugal, como tal, teve pouco significado, no Brasil continua a revelar-se como fenómeno até certo ponto actual, com os seus próprios templos. De resto, Comte foi objecto de veneração de brasileiros, quer na que foi a sua casa em Paris (na rue Monsieur-le-Prince), quer na sua sepultura, no famoso cemitério do Père Lachaise.

Ligados ao Positivismo, os republicanos esforçaram-se por se apropriar dos centenários que se realizaram no fim do século XIX ${ }^{72}$, sobretudo o de Camões (1880) — da suposta morte do poeta, em 1580 - , mas em especial o do Marquês de Pombal (1882), cuja morte se verificou em 1782. A partir daí surgiram centenários sobre os mais variados acontecimentos e personalidades, retorquindo a Igreja também com os seus próprios, como sucedeu com o de Santo António (1895). No domínio nacional ou imperial, revelaram-se os centenários celebrativos da expansão e dos descobrimentos, embora o do Brasil tivesse apenas sido alvo de um centenário oficial, sem as festas cívicas de rua que os republicanos positivistas procuravam promover.

Os 'feriados nacionais' são quase uma invenção republicana, embora inspirados também na festa religiosa dos 'dias santos'. Estas festas religiosas, alguns acontecimentos, como os aniversários de membros da família real, alguns eventos nacionais, como a Restauração, apesar de um impacto limitado do impulso que lhe foi dado pela Comissão Central 1. ${ }^{\circ}$ de Dezembro de 1640 depois de 1861 (em oposição ao iberismo), eram festejados na corte como 'dias de gala' ou de 'grande gala'. Mas o feriado como dia sem trabalho ou de descanso só surgiu, verdadeiramente, quando se começou a falar (invocando motivos de natureza fisiológica) da importância do descanso semanal, em ligação com a ideia internacional do dia de trabalho de 8 horas, cuja luta veio a ser celebrada no dia 1 de Maio, comemorativa dos tumultos de Chicago de 1886. O descanso semanal, coincidente com a tradição do domingo ('dia do Senhor') só surgiu, em Portugal, no tempo do polémico governo de 
João Franco (1907) e, depois, com as leis da República, da responsabilidade directa do médico e militante republicano António José de Almeida, ministro do Interior do Governo Provisório da República (1910-1911) e que veio a ser o primeiro estadista a visitar o Brasil, em Setembro de 1922, ano do primeiro centenário da Independência ${ }^{73}$.

Deste modo, não nos custa a entender que só na I República (fundada em 5 de Outubro de 1910) e logo no seu início (13 de Outubro de 1910) se possa falar da primeira legislação que cria os feriados, todos eles cívicos, numa homenagem à República, à Pátria e à Humanidade: 1 de Janeiro, consagrado à 'fraternidade universal'; 31 de Janeiro (data da nossa primeira revolução republicana, no Porto, em 1891), consagrado aos 'precursores e aos mártires da República'; 5 de Outubro (data a nossa revolução republicana vitoriosa, de 1910), consagrado aos 'heróis da República'; 1 de Dezembro (data da nosso movimento nacional em busca da independência, em 1640, dado que Portugal, e assim o Brasil, esteve ligado à coroa de Espanha, desde 1580), consagrado à 'autonomia da pátria portuguesa'; e o dia de Natal, 25 de Dezembro, que era laicizado como o feriado consagrado à 'família'. Em 1 de Maio de 1912, juntava-se o feriado de 3 de Maio, 'data gloriosa do descobrimento do Brasil', seguindo a tradição (historicamente errada) de que Cabral havia aportado a terras do Atlântico Sul, nesse dia, atribuindo-lhes, por ser dia da Santa Cruz, aquele nome ou designando-as por 'terras de Vera Cruz'; e só em 25 de Maio de 1925, já quase no fim da I República, "é considerada nacional a Festa de Portugal que se celebrará no dia 10 de Junho", data mais que duvidosa, que já era festejada em Lisboa, da morte de Camões, cujo centenário do nascimento (também em data duvidosa) se festejou em 1924.

Curiosamente este naipe de feriados manteve-se, com as mesmas evocações cívicas, durante a Ditadura Militar e a fase mais significativa do Estado Novo, que sempre se considerou (e isso constituiu uma realidade) apoiado pela Igreja Católica. Apesar de a lei de bases da Educação Nacional (1936) levar à afixação do crucifixo nas escolas primárias e dos manuais escolares conterem referências católicas e de em 1940 ter sido assinada a Concordata entre o governo português e a Santa Sé, só em 1948 surgiu um feriado, por assim dizer, religioso, mas por lei da Assembleia Nacional, o 8 de Dezembro, dia da Imaculada Conceição, que, na verdade, era também, ou fundamentalmente, um feriado ligado á história nacional, pois nesse dia, em 1646, Nossa Senhora 
da Conceição havia sido considerada padroeira do Reino de Portugal, de novo autónomo depois de 1640. Verdadeiramente, a introdução dos feriados religiosos só surgiu em 1952, sacrificando-se o 31 de Janeiro e o 3 de Maio em favor de três datas caracteristicamente religiosas: o Corpo de Deus, móvel, a Assunção de Nossa Senhora (15 de Agosto) e Todos os Santos (1 de Novembro). Além disso, tomaram designações religiosas dois feriados já existentes: 25 de Dezembro, agora o Natal, e 1 de Janeiro, a Circuncisão de Cristo.

Depois do 25 de Abril surgiram mais dois feriados cívicos - o 1 de Maio, dia do Trabalhador (legislação de 27 de Abril de 1974), e o 25 de Abril, dia da revolução democrática que terminou com o Estado Novo (legislação de 18 de Abril de 1975) - e, curiosamente (prova da incapacidade de distinguir o profano do sagrado e de tornar a sociedade laica), um feriado religioso, decretado pelo Estado, a sexta-feira santa, que celebra a morte de Cristo (legislação de 12 de Abril de 1976), tornando 'obrigatório' um feriado que até aí era facultativo, e considerando a Páscoa (obrigatoriamente ao domingo, por isso sempre um dia de descanso) também como feriado (legislação de 27 de Agosto de 2003) . Por outro lado, houve desde 21 de Agosto de 1974 a tentativa de generalizar o feriado de cada município, prática que tinha sido iniciada legalmente com a I República e que fora extinta, em 1952, por Salazar, embora fossem consideradas algumas excepções,.

A integração do domingo de Páscoa em 2003 marcava o início da mudança de paradigma para considerar os feriados, dado que a legislação a que nos referimos era o primeiro Código do Trabalho. Ou seja, embora anterior legislação já apontasse para isso, tendo em conta que os feriados eram também questões relacionadas com o trabalho, o certo é que se começava a acentuar a importância dessa realidade, ainda que no sentido de garantir direitos aos trabalhadores. Mas, assim como foram garantidos, foram retirados e, desta forma, neste ano de 2012, já numa lógica inteiramente economicista, o Governo PSD/CDS (Partido Social-Democrata e Centro Democrático Social), com o apoio da Assembleia da República, de maioria absoluta PSD/CDS, e com a colaboração do Presidente da República (que promulgou a lei, sem duvidar da sua constitucionalidade), foi aprovada uma alteração ao Código do Trabalho, retirando sem qualquer discussão na sociedade, a partir de 2013, dois feriados cívicos, o 1 de Dezembro, símbolo da autonomia de Portugal, e o 5 de Outubro, comemorativo da República — que criou a bandeira e oficializou o hino - 
quando, nos dois anos transactos, o Governo (então do PS, Partido Socialista) promovera oficialmente o seu centenário, que foi celebrado em todo o país, muito especialmente nas escolas. Por outro lado, o Governo fez com que a Igreja considerasse duas festas religiosas que passariam a não ser consideradas feriados nacionais, opção que recaiu, pela escolha do Vaticano, na festa do Corpo de Deus e na de Todos os Santos, mantendo, porém, uma condição de superioridade em relação à decisão do Governo, dado que aprovou este acordo com a condição de os feriados religiosos serem reconsiderados depois de cinco anos passados, ou seja, em 2018.

Entre muitas críticas a esta decisão, de pessoas e instituições, deve destacar-se a dos historiadores, que escreveram um documento de protesto, baseado em argumentos sociais e em argumentos históricos. Fui um dos signatários do documento, datado de 5 de Dezembro de 2011, acrescentando a esta posição do corpo profissional de que faço parte, a crítica pessoal, exposta em alguns artigos de jornais ${ }^{74}$.

Com o exemplo deste caso, apenas pretendi chamar a atenção para duas situações. Uma, já referida: a falta de cultura dos políticos que esqueceram completamente a História, reduzindo a decisão apenas a meras questões de ordem económica. Outra: a importância da História para interpretar os factos do presente e intervir sempre que necessário, mesmo que não haja efeitos imediatos. Esta deve ser, na verdade uma das características do historiador e do professor de História, isto é, para além de deverem saber investigar e saberem ensinar, devem intervir na sociedade, directa e responsavelmente.

Ofício do historiador (e do professor de História): ensino e pesquisa (e intervenção pública)

O XV Encontro Regional de História, promovido pela ANPUH - Rio de Janeiro, para que tive a honra de ser convidado, teve como título Ofício do historiador: ensino e pesquisa. Não alterei a palavra 'pesquisa' (que na nossa gramática é menos usual que a palavra 'investigação'), não só porque ela é igualmente por nós utilizada, mas também porque a considero porventura mais correcta, dado que, como nas línguas anglo-saxónicas e noutras línguas latinas, se faz uma distinção entre a investigação em geral (a investigação criminal, por exemplo) e a pesquisa científica. Todavia, resolvi acrescentar entre 
parênteses o ofício do 'professor de História' (de qualquer grau de ensino), a quem esta lição também se destina, pois pode haver professores de História que não sejam rigorosamente investigadores ou pesquisadores, como pode haver professores de Física ou de Biologia que não sejam, em rigor, físicos ou biólogos. Em Portugal alguns são, e talvez cada vez mais devido à crescente falta de lugares na Universidade, mas outros não o são e nunca pensaram sê-lo, ainda que todo o meu discurso fosse no sentido de que todo o professor de História deve ser, em certo sentido, um pesquisador.

Conforme disse, eu que entendo ser a História uma Ciência - Mattoso, pese embora apelar para o rigor da História, acabou por parecer considerá-la um 'Saber' e não uma Ciência, esquecendo que em qualquer ciência, e não apenas na História, não há um conhecimento terminado e olvidando que o objecto de qualquer ciência, por mais real que ele seja, é também sempre 'uma representação' 75 - julgo que ela deve ser entendida como um conhecimento objectivo e não como uma 'opinião', subjectiva ou intersubjectiva. Esta é, como dizia, a grande linha da reflexão que tenho acerca da História, cujas fontes não são apenas, embora o sejam fundamentalmente, os documentos (que podem ser escritos, mas ainda orais ou materiais, de variado tipo), mas também o que se escreveu e publicou, no domínio da História e das mais variadas áreas do saber. Acima de tudo, o historiador, como há muito dizem os teóricos da História, desde Marc Bloch ou Geofrey Barraclough, professor em Oxford ${ }^{76}$, deve ser um homem do presente que analisa o passado mas nunca entende a História como uma ciência do passado. Tem de usar a imaginação criadora e olhar bem para tudo o que o rodeia, pois só assim introduz a novidade no seu discurso, que afinal é uma 'ficção', não uma 'ficção literária' (sem limites), mas científica, pois, por mais rigoroso que seja, todo o discurso histórico é uma 'modelação'. A busca das fontes, a sua "leitura" e a sua interpretação é, pois, tanto mais original e libertadora quanto ele souber integrar o passado no seu contexto sincrónico e diacrónico. É conhecida a ideia de Benedetto Croce de que a História é 'sempre contemporânea', ou seja, é uma interpretação do passado no presente ${ }^{77}$. Se essa ideia não nos fizer cair no 'presentismo', que caracteriza a historiografia ideológica e o revisionismo, é uma concepção correcta e a ter sempre presente.

Por este motivo, como se sabe, a 'escola dos Annales' e da 'nova História' inicial apontaram para uma 'História social', afastando o que se chamou 
(talvez erroneamente) a 'história política', a história positivista (outro conceito ambíguo e de utilização perigosa), a histoire bataille e a 'história individual' (não tanto a 'história biográfica'). Foi uma profissão de fé mal interpretada ou usada abusivamente, pelo que originou depois a reacção radical de alguns historiadores, como sucedeu em Portugal com Maria de Fátima Bonifácio ${ }^{78}$. Nunca me coloquei nessa posição, mas segui com algum interessa as primeiras desconstruções da 'História nova'79 e afinal a própria evolução no sentido de dar um outro rumo à chamada "História nova", concepção que sempre evitei, nunca caindo, todavia, em concepções pós-modernistas, que opunham à chamada 'História total' (que afinal sempre entendi apenas como um objectivo) a uma “'História ultra-especializada' (como o modismo da 'história de géneros') e relativista. A 'História social' não deve nunca ser entendida, nem com uma História teoricamente sociologista (em que, por exemplo, impera o marxismo como sistema), nem deve impedir a história das batalhas, nem a história biográfica, nem deve levar a pensar que a história da cultura se deve reduzir à "história das mentalidades". Eu que sou um historiador da História política e das ideias nunca pensei assim, ao dar relevo à 'História social' entendida como conhecimento da sociedade, assim como nunca me entusiasmei pelas concepções de 'história cultural' de Peter Burke, que criaram uma espécie de modelo. Ao invés, talvez porque fui formado na historiografia francesa, já adiro às concepções sobre história cultural de Roger Chartier ${ }^{80}$.

Julgo que o historiador deve ser, como todo o cientista, independente de qualquer ideologia política ou científica ${ }^{81}$, ainda que entenda que a ideologia faz parte da cultura e como tal deve ser analisada criticamente. Por isso sempre digo, quando hoje se fala tanto em 'massa crítica', que, mais do que a importância deste conceito, fundamentalmente quantitativista e baseado numa ideia de dinâmica construtivista (hoje fala-se constantemente de 'concorrência' e 'competitividade', e de 'competências', do conceito por vezes vazio de 'excelência', de 'empreendedorismo' e do neologismo ridículo de 'alavancagem'), é necessário combater o ‘seguidismo' e usar constantemente a 'consciência crítica'. É essa consciência critica que deve levar o historiador (como outro cientista) e o professor de História à 'intervenção pública'. Foi por essa razão que tomei a liberdade de agora acrescentar essa expressão ao título deste parágrafo inspirado no título do colóquio. 
Esta é afinal a atitude de base de qualquer historiador, como de qualquer outro cientista, assim como deve ser de um professor de História ou de outra qualquer ciência. É mesmo, afinal de contas, a mola real de um homem de Cultura, que não se limita a armazenar e a aceitar como boa qualquer forma de saber ou de sentir (em cinema, em música, em arquitectura ou em qualquer forma de arte, em literatura, etc.), ou de ensinar (com as suas teorias pedagógicas) ou de informar ou de aceder à informação (onde os meios tecnológicos mais variados estão na mesa, com meios informáticos cada dia diferentes e - dizem-nos - mais actualizados: tablet ou iPhone...), mas deve analisar essas formas (que em geral se situam mais no domínio da forma, das performances, do que da matéria ou substância) com "consciência crítica". Hoje trabalho com computador e acedo constantemente a portais, sites, blogues (só recuso integrar-me em redes sociais, como o facebook), mas não olho com desdém para o passado, altura em que se escrevia com a caneta ou com a pena, em que o ficheiro ou base de dados (database, como hoje se diz) eram fichas de cartolina, assim como não penso que éramos menos cultos, quando dispúnhamos só de rádio, ou nem isso, e não tínhamos televisão ou a televisão se reduzia a um canal e quando se falava menos, ou não se falava, em globalização, mas em humanidade, em ecumenismo, em cosmopolitismo, mas também, infelizmente como hoje, em autoritarismo. Todo o saber e toda a arte são diferentes de época para época e, assim, parafraseando a ficção de Carlos Ruiz Zafón, deveríamos manter vivos todos os livros que lemos, ter presentes todos os filósofos, rever-nos na arte de cada época, recordar a História que faziam os nossos mestres e não admitir - como hoje lamentavelmente é costume, dado que estamos no tempo da informação - que quem aborda qualquer tema o faça sem saber o que foi já escrito sobre ele.

Como tenho contado noutros textos, o grande historiador Vitorino Magalhães Godinho falava-me há alguns anos atrás (nos finais dos anos 70), como vício a romper, do que chamava "síndrome da Monarquia Lusitana", isto é, o mau hábito que então tinham os historiadores de recuarem às origens longínquas (como a historiografia dos monges de Alcobaça, que recuava, para escrever a História de Portugal, da 'Monarquia Lusitana', a Adão e Eva), citando tudo, o que interessava e o que não interessava. Mas também, ao invés, não devemos cair no que eu chamo a 'síndrome dos Descobrimentos' muito comum entre os novos historiadores de hoje, ou seja, ter a ilusão de 
que descobriram tudo com a, por vezes, bem modesta pesquisa, esquecendo o que os outros historiadores já fizeram. Por isso é importante a história da História, no sentido amplo e no sentido restrito, isto é, procurar conhecer e descodificar o que se escreveu sobre um tema ou à volta dele antes de se iniciar os estudos com vista à sua pesquisa e interpretação.

É isto que vos posso dizer. Com a minha experiência de quase 50 anos de aprendiz de historiador e de historiador, de professor de História (do Ensino Secundário e do Ensino Superior), de homem do mundo, eu e as 'minhas circunstâncias', filho de um pai conservador e monárquico, que me tornei católico progressista e, depois, agnóstico, socialista democrático e independente (e adversário do neoliberalismo), que andei na Guerra Colonial, que escrevi livros de História de 1966 até hoje, que publiquei artigos da mais variada espécie em revistas e jornais. Perdoem se falei talvez mais de mim e das 'minhas circunstâncias' do que da História na sua dimensão universal da História por que constantemente me tenho batido em "novos combates" 82 como este. 